\title{
Territoriality in Judaism and Islam: Early Concepts and Modern Application
}

\author{
Ondrej Filipec \\ Faculty of Law \\ Palacky University in Olomouc \\ ondrejfilipec@gmail.com
}

\begin{abstract}
Despite the almost 1500 years of coexistence between Islam and Judaism, both religions play a dominant role in the Palestine-Israeli conflict. Besides religion, this conflict has its territorial dimension which dominates the relationship between Israel and Palestine, or rather between Jews and Arabs. This article explores the concept of territoriality within Judaism and Islam and its implications for the Israeli-Palestine conflict. It posits the question: is there any space for peaceful territorial coexistence by two antagonist religions, or just the promise of violent struggle based on different perceptions of territoriality?
\end{abstract}

Keywords: Territoriality, Islam, Judaism, Zionism, Islamism, geopolitics Słowa kluczowe: terytorialność, islam, judaizm, syjonizm, geopolityka

\section{Introduction}

Territoriality has two particular meanings. ${ }^{1}$ First, it might be a persistent attachment to a specific territory or refer to territorial status. In the second sense, territoriality is a pattern of behaviour associated with the defence of territory, which may be observed mainly among certain animal species. In this article, territoriality is understood as territorial status in the context of two religions: Judaism and Islam. For the purposes of the article, territoriality may be defined as: "the attempt by an individual or group (x) to influence, affect, or control objects, people, and relationships (y) by delimiting

1 Many thanks to Professors Aaron T. Walter and Marek Hrusovsky for their comments on previous versions of this article and the two anonymous reviewers for their valuable recommendations. 
and asserting control over a geographic area."2 Special emphasis will be placed on the territorial control and the theoretical concepts of the territory. The importance of territory is not stable, as it may lose or gain significance over time, and the approach towards territory may develop from subjective or objective factors. ${ }^{3}$ In the religious context, with reference to the historical events there are some places which are of central focus. This article explores the theoretical status of central places which are common for Judaism and Islam, with a special focus on Jerusalem.

This exploratory article is divided into three parts. The first part presents the concept and selected religious sources of territoriality in Judaism. Similarly, the second part presents early territorial concepts within Islam. The third part presents the possibility for synthesis of the Jewish and Islamic concepts, and attempts to identify similar and diverging lines. Exploring the concept of territoriality within religion is important and may clarify the causes of political actions taken by political leaders, as they sometimes justify their actions on religious grounds. Moreover, it is religion which significantly shapes people's perceptions and partially influences their opinions on the rights to territory ownership, legality and legitimacy.

Many misunderstandings result from incorrect translation and intentional or unintentional misinterpretation. There are various translations of the Quran and the Bible, some written in very archaic language and in various quality. For the purposes of this article, the primary source of reference used is The Holy Qur'ân. Translation and Commentaries, published in 2010 in Istanbul by Nurettin Uzunoğlu ${ }^{4}$ and representing a balanced and moderate version of Islam. As for reference to the Bible and biblical resources, the portal biblehub.com was used as the most accessible online source, with integrated research tools including cross-references and secondary text references.

\section{Territoriality in Judaism}

Land has principal significance in classical Judaism in concrete and theological terms. The Eretz Yisrael (Land of Israel) represents an original concept of territory of Canaan that God promised to Abraham and gave to the people of Israel. ${ }^{5}$ The order to leave and find a new home for Abraham's people is the subject of Genesis 12: "The LORD had said to Abram, 'Go from your country, your people and your father's household to the land I will show you. I will make you into a great nation, and I will bless you; I will make your name great, and you will be a blessing. I will bless those who bless you, and whoever curses you I will curse; and all peoples on earth will be blessed through you.' So Abram went, as the LORD had told him; and Lot went with

\footnotetext{
2 R.D. Sack, Human Territoriality: A Theory, "Annals of the Association of American Geographers" 1983, vol. 73, no. 1, pp. 55-74.

3 D. Grant, Territoriality: Concept and Delimitation, “The Australian Surveyor" 1998, vol. 42, no. 3, pp. 19-24.

${ }^{4}$ N. Uzunoğlu, The Holy Qur'ân. Translation and Commentaries, Istanbul 2010.

5 J. Neuser, A.J. Avery-Eck, The Routledge Dictionary of Judaism, New York 2004, p. 35.
} 
him. Abram was seventy-five years old when he set out from Harran. He took his wife Sarai, his nephew Lot, all the possessions they had accumulated and the people they had acquired in Harran, and they set out for the land of Canaan, and they arrived there" (Gen. 12:1-5). The territorial dimension of Canaan is revealed in Numbers. ${ }^{6}$ The Promised Land is also mentioned repeatedly in the Torah. For example, in the Book of Shemot: "and I am come down to deliver them out of the hand of the Egyptians, and to bring them up out of that land unto a good land and a large, unto a land flowing with milk and honey; unto the place of the Canaanite, and the Hittite, and the Amorite, and the Perizzite, and the Hivite, and the Jebusite" (Ex. 3:8). A more specific description may be found in the later verses: "I will fix your boundary from the Red Sea to the sea of the Philistines, and from the wilderness to the River Euphrates; for I will deliver the inhabitants of the land into your hand, and you will drive them out before you" (Ex. 23:31). This is the biggest area described, also covering today's territories of Syria and Jordan. The promised land is later tightened slightly, as the First Book of Chronicles refers to the Israel from Beersheba to Dan: "So David said to Joab and to the princes of the people, 'Go, number Israel from Beersheba even to Dan, and bring me word that I may know their number"' (1 Chr. 21:2). The control of Beersheba and Dan more precisely reflects the current situation. ${ }^{7}$

Moreover, the promise of the land is also mentioned in extra biblical sources, including the Apocrypha and Pseudepigrapha, Qumran Writings or the Rabbinic sources, ${ }^{8}$ and is the subject of Mitzvah (Biblical commandments). For example, in Ramban, the commentary on Maimonides's Codification of Biblical Precepts is written: "The fourth mitzvah that we were commanded is to conquer the land that God gave to Abraham, Isaac and Jacob, and not to abandon it to the hands of other nations or to emptiness." A special focus in Judaism is placed on the control of Jerusalem, whose sanctity and biblical centrality serves as a definitive image and symbol

6 "Your southern side will include some of the Desert of Zin along the border of Edom. Your southern boundary will start in the east from the southern end of the Dead Sea, cross south of Scorpion Pass, continue on to Zin and go south of Kadesh Barnea. Then it will go to HazarAddar and over to Azmon, where it will turn, join the Wadi of Egypt and end at the Mediterranean Sea. Your western boundary will be the coast of the Mediterranean Sea. This will be your boundary on the west. For your northern boundary, run a line from the Mediterranean Sea to Mount Hor and from Mount Hor to Lebo Hamath. Then the boundary will go to Zedad, continue to Ziphron and end at HazarEnan. This will be your boundary on the north. For your eastern boundary, run a line from HazarEnan to Shepham. The boundary will go down from Shepham to Riblah on the east side of Ain and continue along the slopes east of the Sea of Galilee. Then the boundary will go down along the Jordan and end at the Dead Sea" (Num. 34:3-12). However, for Gadites and Reubenites and half of the Manasseh tribe there is an extension beyond the River Jordan (Num. 32). Moreover, other boundaries are mentioned in Deut. (1:7 and 11:24) and in Josh and Ezek. (47:15-20).

${ }^{7}$ Beersheba is the largest town, just $30 \mathrm{~km}$ from both borders with Egypt and the Gaza Strip, although Gaza was not considered to be part of Eretz Yisrael: "The territory of the Canaanite extended from Sidon as you go toward Gerar, as far as Gaza; as you go toward Sodom and Gomorrah and Admah and Zeboiim, as far as Lasha" (Gen. 10:19). Gaza was not taken from the Philistines at the time of Solomon.

8 W.D. Davies, The Territorial Dimension of Judaism, Los Angeles 1982.

${ }_{9}$ R.K. Brander, The Mitzvah of Living in the Land of Yisrael: Is it a Biblical Commandment?, http://www.yutorah.org [access: 12.07.2016]. 
of a sacred place. ${ }^{10}$ Despite the area of Canaan developed over time, the differences in the size were not significant. However, due to the inhabitancy of a heterogeneous population and natural migration in the area the borders of Eretz Yisrael were flexible. ${ }^{11}$

When Romans exiled the Jews in $135 \mathrm{CE}$, they were confronted with a new brutal reality which contributed to a deeper land obsession. In other words, the value of the territory increased..$^{12}$ The loss of control over territory in Judaism is connected with physical, existential problems on the one hand and spiritual punishment by God on the other. Living outside of Israel is considered as unnatural for Jews. Land outside is seen as "Galut" (in Hebrew) or "Golus" (in Yiddish), a word with a broad meaning translated as diaspora, exile, captivity or even spiritual limitation..$^{13}$ Galut thus highlights the psychological importance of the land as the existential condition for the Jews.

The lost land, and especially Jerusalem, attracted Jewish attention even during times of Christian or Muslim hegemony, when the spiritual advantage of living in the Promised Land exposed the Jewish community to danger. ${ }^{14}$ During this time, the Jews did not seek domination or question the control of dominant powers. ${ }^{15}$ The situation changed in the nineteenth century, when modern Jewish Zionism constituted a political programme as a response to anti-Semitic discrimination and persecutions of Jews in Europe. As expressed by Theodor Herzl: "The Jewish question exists wherever Jews live in perceptible numbers. Where it does not exist, it is carried by Jews in the course of their migrations. We naturally move to those places where we are not persecuted, and there our presence produces persecution." ${ }^{16}$ To a great degree, the sentiment for the lost land formed the political content of modern Jewish Zionism as a territorial ideology. ${ }^{17}$ Despite this, territory was secondary in Herzl's ideas: "It is true that the Jewish State is conceived as a peculiarly modern structure on unspecified territory. But a State is formed, not by pieces of land, but rather by a number of men united under sovereign rule. The people is the subjective, land the objective foundation of a State, and the subjective basis is the more important of the two." 18 However, Herzl had specific ideas about the place where the Jewish state should be established, mentioning Argentina or Palestine, ${ }^{19}$ which had been under Ottoman rule

${ }^{10}$ R. Firestone, Jerusalem: Jerusalem in Judaism, Christianity and Islam [in:] Encyclopedia of Religion, L.I. Levine (ed.), New York 2009.

${ }^{11}$ K.W. Whitelam, The Invention of Ancient Israel: The Silencing of Palestine History, New York 2009.

${ }^{12}$ D. Grant, op.cit., p. 19.

${ }_{13}$ P. Schindler, Hasidic Responses to the Holocaust in the Light of Hasidic Thought, New Jersey 1990.

${ }^{14}$ A superior biography of the city can be found in S.M. Sebag, Jerusalem: The Biography, London 2012.

${ }^{15}$ R. Firestone, Territoriality and Sanctity in Judaism and Islam, "Central Conference American Rabbis Journal" 2000, Fall, pp. 6-15.

${ }_{16}$ T. Herzl, The Jewish State, New York 2008, p. 28.

${ }^{17}$ G.M. Burge, Jesus and the Land, London 2010.

${ }_{18}$ T. Herzl, op.cit., p. 54.

${ }^{19}$ Herzl was in favour of the logic of opportunity in the case of Argentina due to the presence of a large Jewish community: "We shall take what is given us, and what is selected by Jewish public opinion. The Society will determine both [Argentina or Palestine] these points." Ibidem, p. 36. 
at the time, and there were also other proposed solutions, including the "Madagascar plan" and its French, Polish, Zionist, Nazi or even Japanese version. The plan was refused by the overwhelming majority of Jewish organisations in Europe. Some stressed the precedent for global Jewish expulsion, while others considered the climate in Madagascar as "insalubrious." 20

The political requirements for the Promised Land, previously seen as unrealistic, were enabled by the tragedy of the Holocaust (Shoah), which again raised the importance and added urgency to the Promised Land. The shadow of the Shoah in the Jewish identity and the new geopolitical context contributed to the change in the perception of the international community, and Jews were allowed to create their state in 1948. Territoriality became part of the politics of independence, and moved closer to realisation.

The Promised Land and Jerusalem became central to the modern Israel state building, and are inseparably connected to citizenship and statehood. The first official statements are present in the Declaration of Establishment of the State of Israel from 14 May 1948, which declared "the establishment of a Jewish state in Eretz Israel, to be known as the State of Israel." 21 There is no explicit definition of borders of Eretz Israel, ${ }^{22}$ because this idea was rejected by 5 to 4 members of the preparatory commission, with the argument that the US declaration of independence also did not designate borders. ${ }^{23}$ This might be considered a victory of revisionist Zionism, ${ }^{24}$ which focused on seizing the whole British Mandate for Palestine, also covering territories on both sides of the Jordan River, above the "practical" Zionism presented by Ben Gurion. Although the Declaration stressed Eretz Israel, statehood in the first two decades of the independent state reflected the concept of Medinat Israel, referring to the Jewish and democratic state of Israel, rather than the Biblical Promised Land. While Eretz Israel may be considered as religious-nationalistic concept, the Medinat Israel focuses on democratic and secular values as a more important element. Although this division is simplified, ${ }^{25}$ both concepts are still present in the Israeli political reality, making the distinction between the political right associated with Eretz Israel and the political left associated with Medinat Israel. For example,

${ }^{20}$ E.T. Jennings, Writing Madagascar Back into the Madagascar Plan, "Holocaust and Genocide Studies" 2007, vol. 21, no. 2, pp. 187-217.

${ }^{21}$ Israel Ministry of Foreign Affairs (IMFA), Declaration of Establishment of the State of Israel, 14 May 1948, http://www.mfa.gov.il [access: 15.06.2016].

${ }^{22}$ The key for setting up the borders of the newly established state was the United Nations Partition Plan for Palestine, approved as Resolution 181(II). According to the plan, the Jewish state was to receive $56 \%$ of the Palestine Mandate. Resolution der General Versammlung verabschiedet am 29. November 1947. 181 (II). Die künftige Regierung Palästinas, Vereinte Nationen, New York 1993.

${ }_{23}$ J. Harris, The Israeli Declaration of Independence, "The Journal of the Society for Textual Reasoning" 1998, vol. 7, no. 1 (old series), p. 38.

${ }^{24}$ Revisionist Zionism, as developed by Vladimir Ze' ev Jabotinsky, articulated romantic nationalism and stressed militaristic values in order to establish a Jewish state on the both sides of the River Jordan. See D. Waxman, The Pursuit of Peace and the Crisis of Israeli Identity: Defending/Defining the Nation, New York 2006, p. 26.

${ }^{25}$ For example there are very religious Jews who adhere to principles of liberal democracy (Meimad Party) or liberal values and secularism (Meretz Party). 
in the Annapolis Conference in November 2007, Israeli Prime Minister Ehud Olmert and Foreign Minister Tzipi Livni both made a particular reference to a "Jewish state" and supported the solution of two states for two peoples. ${ }^{26}$ Similarly, during his campaign, Benjamin Netanyahu decided to honour the labour compromises based on the 1993 Oslo Accord and Palestinian Self Rule. On the other hand, this political shift was strongly criticised by Ariel Sharon, who emphasised the concept of Eretz Israel. ${ }^{27}$ Netanyahu was forced to look for a compromise between the two concepts during his second term in the office as prime minister: to continue with the Road Map but refuse to freeze settlements in the West Banks. ${ }^{28}$

The importance of independence is also visible in the Israeli anthem Hatikvah (Our Hope), which also refers to sentiments for the homeland: "As long as in the heart, within, / A Jewish soul still yearns, / And onward, towards the ends of the east, / an eye still gazes towards Zion; / Our hope is not yet lost, / The hope two thousand years old, / To be a free nation in our land, / The land of Zion and Jerusalem." The Holocaust added urgency to the state building and highlighted the biblical importance of the Eretz Yisrael in contemporary times. Nevertheless, the centrality of Israel and Jerusalem is mentioned in many sources. As for Ezekiel in the Tanakh: "Thus says the Lord GOD, This is Jerusalem; I have set her at the centre of the nations, with lands around her" (Ezek. 5:5). In Zechariah, it is mentioned that Jerusalem is the city where God dwells: "Thus says the LORD, I will return to Zion and will dwell in the midst of Jerusalem. Then Jerusalem will be called the City of Truth, and the mountain of the LORD of hosts will be called the Holy Mountain" (Zech. 8:3).

Jews fought several wars to defend territories of the newly established state. The 1948 war is seen differently by Jews and Arabs. While Jews refer to the conflict as the War of Independence, Arabs sees the loss of territory as an-Nakba (Catastrophe) which further intensified after the outbreak of the Six Days War in June 1967 when Israel succeeded in expanding its control over the Sinai Peninsula, West Bank and Golan Heights. This was the first time in history when Jews controlled territories better matching the biblical boundaries. This shifted the focus of the Israel politics from Medinat Israel to Eretz Israel. This situation was intensified after the almost lost war of 1973, as well as the 1977 elections, which ended the dominance of the Labour Party. ${ }^{29}$

Jews focus on the single territory for early revelations in ancient times. From this point of view, the nature of the Jewish religion and Jewish approach may be seen as spiritually defensive while the promised land is under Jewish control, and sentimentally offensive when occupied or threatened. This, however, does not mean that the defensive attitude is less violent than the offensive one, taking into account the expansion of settlements, which intensified after 1977. According to Israeli sources,

\footnotetext{
26 A. Susser, Israel, Jordan and Palestine. The Two-State Imperative, Waltham 2012, p. 107.

27 J. Greenberg, The World: Pursuing Peace; Netanyahu and His Party Turn Away from 'Greater Israel', "The New York Times" 1998, 22 November.

${ }^{28}$ B. Ravid, A. Benn, Netanyahu's Speech: Yes to Road Map, No to Settlement Freeze, "Haaretz" 2009, 11 June.

${ }^{29}$ D.A. Del Sarto, Israel's Contested Identity and the Mediterranean, Jerusalem 2002, p. 8.
} 
there are 1.7 million Israeli Arabs in Israel, comprising approximately $21 \%$ of the Israeli population. This causes tension within the State and opens the question of territoriality in Islam. This is an increasingly important question, as the self-identification of Israeli Arabs with Israel is decreasing, and almost half of all Israelis call for Arab expulsion. ${ }^{30}$ Yet there are significant differences between the understanding of territoriality among Muslims living in Palestine and those of Muslims living in less contested areas.

\section{Territoriality in Islam}

There is no explicit concept of a territorial or national state in Islam. The territorial dimension was developed later by Islamic scholars..$^{31}$ In the traditional views, the world is divided between Dar al-Islam (The house of Islam), where Muslims are living under Islamic law, and Dar al-Harb (The house of War), the territory with an absence of Islamic law which is inhabited by non-Muslims. ${ }^{32}$ However, there are more expressions, with slightly different connotations to both terms. For example, Dar al-Islam is sometimes referred as Dar al-Salam (The house of Peace), where the word "Salam" (Peace) is more than simply the absence of war, but rather the state of harmony. ${ }^{33}$ As mentioned in the Quran: "And Allah invites to the Home of Peace and guides whom He wills to a straight path" (Q 10:25). Dar al-Harb is similar to Dar al-Gharb (The house of the West) or also Dar al-Kufr (The house of Disbelief). ${ }^{34}$ According to Ulema, Dar al-Harb may be further divided into Dar al-Harb Fi'lan (actual land of war) and the Dar al-Harb Hukman (potential land of war). Most Muslims understand Israel as Dar-al Harb Fi'lan, which is accelerated by the historic dominance over territory and its previous incorporation into Dar al-Islam. ${ }^{35}$ Dar al-Harb is often seen as the land of infidels and ignorance, which is a threat to Muslim order. ${ }^{36}$ Participating in the war against Dar al-Harb was originally fard al-kifaya, a moral obligation

${ }^{30}$ M. Newman, Nearly Half of Jewish Israelis Wants to Expel Arabs, Survey Shows, "The Times of Israel" 2016, 8 March.

${ }^{31}$ R. Firestone, Territoriality and Sanctity in Judaism and Islam, "Central Conference American Rabbis Journal" 2000, Fall, pp. 6-15.

${ }^{32}$ The word "Harb" expresses the use of force by non-Muslims. On the contrary, there is a word "Futuhat," which refers to opening the World to Islam. See B. Tibi, War and Peace in Islam [in:] Islamic Political Ethics: Civil Society, Pluralism, and Conflict, S.H. Hashmi (ed.), Princeton 2002, p. 188.

${ }_{33}$ S.H. Hashmi, Interpreting the Islamic Ethics of War and Peace [in:] Islamic Political Ethics..., op.cit., p. 197.

${ }^{34}$ The reality of a Muslim World was expressed by Mehmed II the Conqueror in the fifteenth century as follows: "Today, he says, the times have changed, and declares that he will advance from East to West as in the former times the Westerners advanced into the Orient. There must, he says, be only one empire, one faith, one sovereignty in the World." See F. Babinger, Mehmed the Conqueror and his Time, Princeton 1978, p. 112.

${ }_{35}$ The Khilafah, Clarifying the Meaning of Dar al-Kufr \& Dar al-Islam, 28 March 2007, http://www. khilafah.com/clarifying-the-meaning-of-dar-al-kufr-a-dar-al-islam/ [access: 16.07.2016].

${ }^{36}$ L. Takim, War and Peace in the Islamic Sacred Sources, "Journal of Shi'a Islamic Studies" 2011, vol. 4, no. 1, pp. 5-22. 
imposed on the whole community (Ummah), ${ }^{37}$ especially for those who were able to wage war, like able-bodied and financially secured adult males. ${ }^{38}$

This Manichaean worldview has been a point of criticism, opening the concept of Dar al-Islam and Dar al-Harb up to varieties of concepts based on the internal division of Islam for conditionality. For example, there is also Dar al-Iman (the abode of true faith): when a territory is governed by Sharia but not based on teachings of the Imam from the family of the Prophet, the territory is considered part of Dar alIslam but not Dar al-Iman. ${ }^{39}$ Moreover, there are several concepts reflecting various statuses of territory between war and peace.

Dar al-Hudna (House of Calm) refers to territory inhabited by non-believers who have agreed on a truce between wars. This concept is very similar to Dar al-Ahd (House of Truce) or Dar as-Sulh (House of Treaty), which refers to the territory inhabited by non-Muslims who have agreed on a mutual peace treaty with provisions on non-aggression. The principles of al-Hudna date back to the times of Prophet Mohammad and the Treaty of Hudaybiyya, signed in the year $6 \mathrm{AH}(628 \mathrm{CE}) .^{40}$

However, the interpretations of the al-Hudna concept vary, with the two views being encapsulated in the dispute between Mustafa Abu Sway (2006) and Marvin F. Zayed (2006). Abu Sway highlights the defensive nature of Islam and bona-fide nature of treaties aiming for the end of conflict and enduring peace between Muslims and non-Muslims, while Marvin F. Zayed considers al-Hudna as a limited period of time in between wars which may end only when a non-Muslim accepts the rule of Islam and pays Jizya or endorses Islam by converting to it. ${ }^{41}$ It is important to note that Zayed is using a linguistic approach towards the explanation of the words. AlHudna is derived from the word Hada'a in the sense of "calmness," such as night, when people go to sleep and interrupt their activity. Thus it is a temporary agreement to stop the war, which does not imply potential for stability or peace in the near future ${ }^{42}$ On the other hand Abu Sway refers to the Quranic duty to honour the treaties, which is based on the Quran: "And fulfil the covenant of Allah, when you have taken it and do not break oaths after their confirmation while you have made Allah, over you, a witness. Indeed, Allah knows what you do" (Q 16:91).

The Maliki school does not specify a necessary time limit. It is up to the head of state to decide on the lime limits of the treaties. However, contrary to the Maliki

${ }^{37}$ Ummah has always been the central point of Islamic doctrine. Etymologically, the word Ummah is possibly a cognate of the Hebrew am and Aramaic Ummetha, which refers to the "people." As Robert Saunders concluded, Ummah may be considered as a nation with competing national identities and also internal religious divisions, and historically has been used in the nationalistic sense. See R.A. Saunders, The ummah as Nation: a Reappraisal in the Wake of the 'Cartoons Affair', "Nations and Nationalism" 2008, vol. 44, no. 3, p. 304.

${ }^{38}$ S.H. Hashmi, op.cit., p. 205.

${ }^{39}$ L. Takim, op.cit., pp. 5-22.

${ }^{40}$ Interpretation of events following the treaty and its violation is a source of academic debate between scholars, as pointed out by A.M. Sway, The Concept of Hudna (Truce) in Islamic Sources, "Palestine-Israel Journal of Politics, Economics \& Culture" 2006, vol. 13, no. 3, p. 27.

${ }^{41}$ M.F. Zayed, Reflections on the Concepts of Hudna and Tahd 'ia, "Palestine-Israel Journal of Politics, Economics \& Culture" 2006, vol. 13, no. 4, p. 103.

${ }^{42}$ Ibidem. 
school, the Shafi'i school sets the limit of the Hudna at 10 years, similarly to the Hudaybiyya Treaty. Without limit specification, the treaty is considered invalid. ${ }^{43}$

It is important to note that in Arabic there is a distinction between "treaty" (a rather neutral word) and the "Sulh," which can be better translated as conciliatory agreement. The concept of Dar as-Sulh has been developed by Shafi'i jurists as abode of truce. ${ }^{44}$ In other words, there is a peace based on a treaty about alliance and cooperation. During peace time, Dar as-Sulh would pay the Jizya or cede a portion of its territory. According to Takim, who refers to the al-Shafi'i school, the truce could not exceed ten years. ${ }^{45}$ Takim also points out that some jurists propose indefinite validity of the treaty as long as it serves the Muslim community, while others do not recognise the existence of Dar as-Sulh. ${ }^{46}$

However, this concept of Dar as-Sulh does not match the current reality and geopolitical situation. For example, Turkish Muslims living in Germany no longer see Germany as Dar al-Harb. Because they can practise the Muslim religion within the constitutional limits, Germany may rather be considered as Dar as-Sulh. ${ }^{47}$ Similarly, full religious rights for Muslims living in Israel will turn the territory from Dar alHarb to Dar as-Sulh, as religious freedom and positive rights equal to the majority population are central to the concept.

There are two other noteworthy concepts: Dar ad-Dawa (House of Invitation) and Dar al-Amn (House of Safety). The first refers to the territory where Islamic law has been newly established, ${ }^{48}$ and the second to the territory where Muslims are allowed to practise their religion but no Islamic government has yet been established. The Quran does not state that force may be used against all unbelievers, but only those who are hostile towards Islam and are trying to undermine the Islamic polity or prosecuting Muslims. ${ }^{49}$ In a very interesting way, Islam combines the territory with the form of government and religious freedom for Muslims. In this sense, Dar al-Islam and Dar al-Harb are a legal construct with a territorial dimension: Dar al-Islam is a political-territorial expression of the community, in which the Islamic religion is practised and where it is protected by a Muslim ruler. Dar as-Sulh is an area where practice of Islam is permitted but there is no Muslim ruler. In the Dar al-Harb, Islam might be practised, but does not enjoy protection of the non-Muslim ruler. ${ }^{50}$

As with Judaism, there are several holy cities within Islam, including Jerusalem. This is mainly due to the Al-Aqsa Mosque, which was designed by the Prophet Muhammad for pilgrimage and served as the first Qibla (the direction of prayer). At the

43 A. Sway, op.cit., p. 27.

44 L. Takim, op.cit., p. 19.

45 Ibidem.

46 Ibidem.

${ }^{47}$ H. Henkel, Rethinking the dar al-harb: Social Change and Changing Perceptions of the West in Turkish Islam, "Journal of Ethnic and Migration Studies" 2004, vol. 30, no. 5, p. 975.

48 A. Black, E. Hossein, H. Nadirsyah, Modern Perspectives on Islamic Law, Northampton 2013, p. 42.

49 L. Takim, op.cit., p. 9.

${ }_{50}$ M. Parvin, M. Sommer, Dar Al-Islam: The Evolution of Muslim Territoriality and its Implications for Conflict Resolution, "International Journal of Middle East Studies” 1980, vol. 11, no. 1, p. 5. 
Dome of the Rock on Temple Mount, Muhammad ascended into heaven and revealed the second pillar of Islam. Moreover, many prophets of Islam, including Jesus, Solomon, Abraham and David, made significant revelations in Jerusalem. Jerusalem is not directly mentioned in the Quran (or in its Arabic transcription "Al Quds," and the centrality of Mecca and Medina is unquestionable, but Jerusalem has significant spiritual value for Muslims as well.

Islam is seen as having a universal set of values, which is the duty to spread into the Dar al-Harb, which means that Islam is prejudiced towards other religious and political systems, including liberal democracies which guarantee religious rights in a non-discriminatory way. Moreover, a gradual shift from innovative reasoning (ijtihad) to imitation (taqlid) makes the evolution of legal norms more challenging, and sometimes fails to keep pace with international developments and reflect the new reality of nation states in the process of globalization..$^{51}$ The early conduct of Islamic rulers or the restoration of the Caliphate as intended by radical Islamist groups and radical jihadist organisations is no more acceptable. As Sohail Hashmi points out, during the first contact between a Muslim state and a foreign power, the power was invited to allow the peaceful preaching of Islam. If it refused, then it was offered to incorporate its people into the Islamic realm as a protected non-Muslim community and to pay Jizya. If it did not agree, a Muslim ruler was required to wage war against them. ${ }^{52}$ Similarly, early Islam does not offer the innovative approach for people connected with the territory, which is most visible in the contemporary reality of the globalised world. ${ }^{53}$ In other words, focusing on early concepts does not match the reality of the contemporary world, and will necessarily lead to a conflict of values.

\section{Israel as Dar al-Amn?}

Despite the Manichaean territorial bias in the early Islamic concepts, there is a certain degree of flexibility in comparison to the Jewish concept of "Eretz Yisrael." The argument of early incorporation of former Canaanite territories into Dar al-Islam is inconsistent in the light of other Muslim territories which have been lost in the past, ${ }^{54}$ but their possession has not been questioned, except by radical Islamists calling for a World Caliphate. The existence of Israel is an indisputable fact supported by international law and treaties. Rather than territory, the focus should be put on Ummah and its peaceful coexistence with other religious groups. There are many examples in history, including Baghdad, Constantinople, or Cordoba, where Muslims and other

${ }^{51}$ M. Burgis, Faith in the State? Traditions of Territoriality, International Law and the Emergence of Modern Arab Statehood, "Journal of the History of International Law" 2009, vol. 11, no. 1, p. 51.

${ }^{52}$ S.H. Hashmi, op.cit., p. 208.

${ }_{53}$ For a detailed status of the people living on these territories see Y. Friedmann, Tolerance and Coercion in Islam. Interfaith Relations in the Muslim Tradition, Cambridge 2003, pp. 54-86.

${ }^{54}$ For example, Rashidun Caliphate controlled Armenia and part of Georgia; Umayyad Caliphate also covered Portugal, Spain and the south of France; Abbassid Caliphate retained control over the Greek island of Crete. 
religions peacefully coexisted and had mutual benefit from religious diversity leading to flourishing of culture and prosperity. Peaceful coexistence is more urgent than at any previous time, as the number of Muslims is absolutely and proportionally increasing in almost all countries around the world, as detailed in a study from the Pew Research Center in 2011.55

In the Quran, Christians and Jews are regarded as the People of the Book (Ahl alKitab), and as such have only certain rights compared to Muslims. For example, there is a concept of protection (Aman) for people coming from Dar al-Harb to Daral-Islam which may last up to one year. The holder is called Musta'min, and for that period of time is not required to pay Jizya. ${ }^{56}$ However, paying tax is in contrast with the democratic value of non-discrimination on areligious basis. Free expression of religion is one of the basic elements for Muslims in the Dar al-Islam, Dar as-Sulh or Dar al-Amn. According to the principle of reciprocity, it should apply to all non-Muslims in Dar al-Harb or Dar as-Sulh. In this sense, in the long term the increasing religious status of Jews in the Dar al-Islam and the similarly increasing status of Muslims in Israel may contribute to a change in the perception of Israel from Dar al-Harb to Dar al-Amn and enable peaceful coexistence based on contemporary values of liberal democracy guaranteeing religious freedom. There is a good beginning engrained in both religions. As for Islam, Muslims should be open for peace (Q 8:61), while in Judaism too there are many passages in Tanakh regarding seeking peace and pursuing it (Le. 26:6; Is. 59:19; Ps. 34:15, 119:165 and others).

\section{Conclusions}

Territoriality has played its role in Judaism and Islam in different ways. Judaism solely focuses on the concept of Eretz Yisrael and the centrality of Jerusalem in pre-modern times. Despite some flexibility of the concept due to the changes in the original location of tribes, the area concerned did not change much. Moreover, territoriality became a key element of Zionism and modern Israeli statehood which is presented in Israeli politics. Territoriality in Judaism has remained within the specific context of the Promised Land, giving a clear demarcation based on very complex sacred sources.

Territoriality in Islam is in some aspects contrary to Judaism. Islam in the history under the Umayyad Caliphate succeeds in covering one of the greatest empires in world history. This historical success and gradual territorial expansion between 622 and $750 \mathrm{CE}$ explains both the prejudice and religious centricity in the Islamic territorial concepts and more abstract ideas in comparison to the Jewish understanding of territoriality. In this sense, it is not surprising that the Muslim Caliphate is based on rather abstract ideas, and over time has been divided by its heterogeneity and colonial dominance, while Jewish tangible ideas were transformed into the modern national

55 Pew Research Center, Table: Muslim Population by Country, 2013, http://www.pewforum. org/2011/01/27/table-muslim-population-by-country/ [access: 14.06.2016].

56 S.H. Hashmi, op.cit., p. 208. 
state which better fits the reality of the twenty-first century. However, even Israel has been forced to make compromises vis-à-vis the international community and domestic pressures, abandoning the orthodox concept of Eretz Yisrael and encouraged to focus more on its civic dimensions better connected to Medinat Yisrael and a twostate solution.

\section{References}

Babinger F., Mehmed the Conqueror and His Time, Princeton 1978.

Black A., Hossein E., Nadirsyah H., Modern Perspectives on Islamic Law, Northampton 2013.

Brander R.K., The Mitzvah of Living in the Land of Yisrael: Is it a Biblical Commandment?, http:// www.yutorah.org [access: 12.07.2016].

Burge G.M., Jesus and the Land, London 2010.

Burgis M., Faith in the State? Traditions of Territoriality, International Law and the Emergence of Modern Arab Statehood, "Journal of the History of International Law" 2009, vol. 11, no. 1, pp. 37-79.

Davies W.D., The Territorial Dimension of Judaism, Los Angeles 1982.

Del Sarto D.A., Israel's Contested Identity and the Mediterranean, Jerusalem 2002.

Firestone R., Jerusalem: Jerusalem in Judaism, Christianity and Islam [in:] Encyclopedia of Religion, L.I. Levine (ed.), New York 2009.

Firestone R., Territoriality and Sanctity in Judaism and Islam, "Central Conference American Rabbis Journal" 2000, Fall, pp. 6-15.

Friedmann Y., Tolerance and Coercion in Islam. Interfaith Relations in the Muslim Tradition, Cambridge 2003.

Grant D., Territoriality: Concept and Delimitation, "The Australian Surveyor" 1998, vol. 42, no. 3, pp. 19-24.

Greenberg J., The World: Pursuing Peace; Netanyahu and His Party Turn Away from 'Greater Israel', "The New York Times" 1998, 22 November.

Harris J., The Israeli Declaration of Independence, "The Journal of the Society for Textual Reasoning" 1998, vol. 7, no. 1 (old series).

Hashmi S.H., Interpreting the Islamic Ethics of War and Peace [in:] Islamic Political Ethics: Civil Society, Pluralism, and Conflict, S.H. Hashmi (ed.), Princeton 2002.

Henkel H., Rethinking the dar al-harb: Social Change and Changing Perceptions of the West in Turkish Islam, "Journal of Ethnic and Migration Studies" 2004, vol. 30, no. 5, pp. 961-978.

Herzl T., The Jewish State, New York 2008.

Israel Ministry of Foreign Affairs (IMFA), Declaration of Establishment of the State of Israel, 14 May 1948, http://www.mfa.gov.il [access: 15.06.2016].

Jennings E.T., Writing Madagascar Black into the Madagascar Plan, "Holocaust and Genocide Studies" 2007, vol. 21, no. 2, pp. 187-217.

Neuser J., Avery-Eck A.J., The Routledge Dictionary of Judaism, New York 2004.

Newman M., Nearly Half of Jewish Israelis Wants to Expel Arabs, Survey Shows, "The Times of Israel" 2016, 8 March.

Parvin M., Sommer M., Dar Al-Islam: The Evolution of Muslim Territoriality and its Implications for Conflict Resolution, "International Journal of Middle East Studies” 1980, vol. 11, no. 1, pp. 1-21.

Pew Research Center, Table: Muslim Population by Country, 2013, http:/www.pewforum.org/ 2011/01/27/table-muslim-population-by-country/ [access: 14.06.2016]. 
Ravid B., Benn A., Netanyahu's Speech: Yes to Road Map, No to Settlement Freeze, "Haaretz" 2009, 11 June.

Resolution der General Versammlung verabschiedeten am 29. November 1947. 181 (II). Die künf tige Regierung Palästinas, Vereinte Nationen, New York 1993.

Sack R.D., Human Territoriality: A Theory, "Annals of the Association of American Geographers" 1983, vol. 73, no. 1, pp. 55-74.

Saunders R.A., The ummah as Nation: a Reappraisal in the Wake of the 'Cartoons Affair', "Nations and Nationalism" 2008, vol. 44, no. 3, pp. 303-331.

Schindler P., Hasidic Responses to the Holocaust in the Light of Hasidic Thought, New Jersey 1990.

Sebag S.M., Jerusalem: The Biography, London 2012.

Susser A., Israel, Jordan and Palestine. The Two-State Imperative, Waltham 2012.

Sway A.M., The Concept of Hudna (Truce) in Islamic Sources, "Palestine-Israel Journal of Politics, Economics \& Culture" 2006, vol. 13, no. 3, pp. 20-27.

Takim L., War and Peace in the Islamic Sacred Sources, "Journal of Shi'a Islamic Studies” 2008, vol. 4, no. 1, pp. 5-22.

The Khilafah, Clarifying the Meaning of Dar al-Kufr \& Dar al-Islam, 28 March 2007, http://www. khilafah.com/clarifying-the-meaning-of-dar-al-kufr-a-dar-al-islam/ [access: 16.07.2016].

Tibi B., War and Peace in Islam [in:] Islamic Political Ethics: Civil Society, Pluralism, and Conflict, S.H. Hashmi (ed.), Princeton 2002.

Uzunoğlu N., The Holy Qur'ân. Translation and Commentaries, Istanbul 2010.

Waxman D., The Pursuit of Peace and the Crisis of Israeli Identity: Defending/Defining the Nation, New York 2006.

Whitelam K.W., The Invention of Ancient Israel: The Silencing of Palestine History, New York 2009.

Zayed M.F., Reflections on the Concepts of Hudna and Tahd'ia, "Palestine-Israel Journal of Politics, Economics \& Culture" 2006, vol. 13, no. 4, pp. 101-103. 